\title{
Retinoic Acid Stimulates $\alpha$-CAMKII Gene Expression in PC12 Cells at a Distinct Transcription Initiation Site
}

\author{
Jing Chen and Paul T. Kelly \\ Department of Neurobiology and Anatomy, University of Texas Medical School at Houston, Houston, Texas 77225
}

The promoter region of the $\alpha$-subunit of the calcium/ calmodulin-dependent protein kinase II ( $\alpha$-CaMKII) gene was inserted into a $\beta$-galactosidase ( $\beta$-gal) reporter plasmid, and $\beta$-gal activities were examined in neuroblastoma (NB2a) and pheochromocytoma (PC12) cells after transient or stable transfections. The $\alpha$-CaMKII promoter was 12 - to 45 -fold more active in NB2a compared with PC12 cells after transient or stable transfections. All-trans retinoic acid (RA) stimulated reporter gene expression at both protein and mRNA levels in transfected PC12 cells. RA increased the level of endogenous $\alpha$-CaMKII mRNA in untransfected PC12 cells by 4.4 -fold. The transcription initiation site(s) (TIS) of the $\alpha$-CaMKII gene in PC12 cells and rat brain was examined by RNase protection assays (RPA) and reverse transcriptase PCRs. The TIS for the
$\alpha$-CaMKII/ $\beta$-gal reporter gene in transfected PC12 cells was indistinguishable from the $\mathrm{TIS}_{+1}$ in rat hippocampus. In contrast, the only detectable TIS for the $\alpha$-CaMKII gene in untransfected PC12 cells was located near the ATG translation start codon, 147 nucleotides $3^{\prime}$ to TIS $_{+1}$ in hippocampus. This unusual TIS was also the predominant TIS in rat cerebellum. These results suggest that the $\alpha$-CaMKII promoter may contain sequences that respond directly or indirectly to RA. In addition, the unusual TIS of the $\alpha$-CaMKII gene in PC12 cells and rat cerebellum may contribute to the very low expression of this gene compared with that in hippocampus.

Key words: retinoic acid; transcription initiation site; $\mathrm{Ca}^{2+}$ / calmodulin-dependent protein kinase II; CaMKII; RNase protection assay
Dramatic differences in expression of the $\alpha$-subunit of calcium/ calmodulin-dependent protein kinase II $(\alpha$-CaMKII) and its mRNA occur during brain development (Kelly et al., 1987; Burgin et al., 1990) and in different brain regions (Erondu and Kennedy, 1985). $\alpha$-CaMKII mRNA and protein are barely detectable in forebrain at postnatal day 5 and increase $\sim 20$-fold by day 25 , a period that coincides with the most active phase of synapse formation. $\alpha$-CaMKII is one of the most abundant protein kinases found in mammalian brain and is highly expressed in the hippocampus (Erondu and Kennedy, 1985; Kelly and Vernon, 1985; Burgin et al., 1990). The developmental and neuron type-specific expression of its mRNA and protein (Kelly et al., 1987; Scholz et al., 1988; Weinberger and Rostas, 1988; Burgin et al., 1990) indicate that $\alpha$-CaMKII gene expression is regulated at the level of transcription. $\alpha$-CaMKII also plays an important role in the induction of long-term potentiation (Malenka et al., 1989; Malinow et al., 1989; Bach et al., 1995; Mayford et al., 1995; Wang and Kelly, 1995). Transgenic studies indicate that $\alpha$-CaMKII may play a role in spatial learning (Silva et al., 1992; Bach et al., 1995), and synaptic plasticity may involve increases in the transcription of $\alpha$-CaMKII mRNA (Mackler et al., 1992; Thomas et al., 1994).

Our initial studies using transfected reporter plasmids indicated that $\alpha$-CaMKII promoter activity was high in neuron-like cells [e.g., neuroblastoma (NB)] compared with that in fibroblasts (Olson et al., 1995). One exception to this relationship is pheochromocytoma (PC12) cells, in which the activity of the

Received Feb. 9, 1996; revised June, 20, 1996; accepted June 24, 1996.

This work was supported by National Institutes of Health Grant NS22452. We thank Youping Xiao and Drs. Norma Olson, Neal Waxham, Thierry Massé, and Peter Davies for helpful discussions and comments on this manuscript.

Correspondence should be addressed to Paul T. Kelly, Department of Neurobiology and Anatomy, University of Texas Medical School at Houston, P.O. Box 20708, Houston, TX 77225.

Copyright (C) 1996 Society for Neuroscience $0270-6474 / 96 / 165704-11 \$ 05.00 / 0$
$\alpha$-CaMKII promoter is extremely low (Massé et al., 1993; Chen and Kelly, 1994). Although many neurons in the CNS express extraordinarily high levels of $\alpha$-CaMKII (e.g., hippocampal pyramidal neurons), principal neurons of the cerebellum express little or no $\alpha$-CaMKII. The mechanisms responsible for such dramatically different levels of $\alpha$-CaMKII expression are largely unknown. The studies presented herein provide new information about the regulation of $\alpha$-CaMKII gene expression. We have used PC12 cells as a model to explore the neuron-type expression of this prominent neuronal protein kinase. We observed that RAinduced differentiation of PC12 cells stimulated $\alpha$-CaMKII expression. Analyses of mRNA transcription initiation sites (TIS) revealed that PC12 cells displayed a distinct TIS that was common to cerebellum and was virtually undetectable in hippocampus. These findings suggest that different mechanisms regulate the $\alpha$-CaMKII gene transcription in different brain regions and determine its neuron-type specific expression.

\section{MATERIALS AND METHODS}

Plasmids. The 5 ' flanking region of the $\alpha$-CaMKII gene was restricted with PstI and AvaI, and the resulting 290 nucleotide (nt) fragment was blunt-ended and ligated into an RC/CMV/ $\beta$-gal plasmid (a gift from Dr. Thierry Massé) derived from pRC/CMV (Invitrogen, San Diego, CA). $\mathrm{RC} / \mathrm{CMV} / \beta$-gal was digested with $\mathrm{NruI}$ and HindIII to remove the CMV promoter, and the resulting $8000 \mathrm{nt}$ fragment was blunt-ended and ligated with the $290 \mathrm{nt}$ fragment to generate $\mathrm{p} \alpha$-CaMKII $/ \beta$-gal. An additional construct was prepared by ligating the $8000 \mathrm{nt} N \mathrm{ruI} / \mathrm{Hin}$ dIII fragment to produce a promoterless plasmid designated $\mathrm{p} \beta$-gal. The parent $\mathrm{pRC} /$ CMV plasmid contains the structural gene for neomycin (NEO) resistance under the control of the SV40 promoter.

Cell culture and transfections. Murine NB2a (a gift from Dr. Tom Shea, Harvard Medical School) or PC12 cells were grown in DMEM $(8-10 \%$ $\mathrm{CO}_{2}$ ) plus $10 \%$ fetal bovine serum (FBS) (NB2a) or 5\% FBS plus $10 \%$ donor horse serum (PC12). Cells were transfected with $15 \mu \mathrm{g}$ of plasmid DNA/100 mm cell-culture dish $(5 \mu \mathrm{g} / 60 \mathrm{~mm}$ dish $)$ by the calcium phosphate method (Graham and van der Eb, 1973). PC12 cells were also 
stably transfected using the Transfectam (Promega, Madison, WI) method (Behr et al., 1989; Loeffler et al., 1990) to increase transfection efficiency. Cells were plated $24 \mathrm{hr}$ before being transfected and then incubated in normal medium containing transfection components in 5\% $\mathrm{CO}_{2}$ for $20 \mathrm{hr}$. Cells were placed in fresh DMEM and incubated in $8-10 \%$ $\mathrm{CO}_{2}$ for $1 \mathrm{hr}$ followed by normal DMEM complete medium containing serum and grown at $8-10 \% \mathrm{CO}_{2}$. After transient transfections, cells were routinely harvested $48 \mathrm{hr}$ later. For stable transfections, individual clones were selected in medium containing G418 $(0.5 \mathrm{mg} / \mathrm{ml}$ for NB2a and 1-3 $\mathrm{mg} / \mathrm{ml}$ for PC12). After 2 weeks, individual clones were picked, expanded, and characterized; the remaining clones were combined and designated "mixed" clones. For studies on the effects of retinoic acid (RA) on gene expression, all-trans RA (5-100 $\mu \mathrm{M}$ final concentration; Sigma, St. Louis, MO) or ethanol $(0.125 \% \mathrm{v} / \mathrm{v})$ was added to complete medium.

Reporter gene assays. Cells were fixed for $10 \mathrm{~min}\left(22-24^{\circ} \mathrm{C}\right)$ in PBS containing $2 \%(\mathrm{v} / \mathrm{v})$ formaldehyde and $0.2 \%$ glutaric dialdehyde; $\beta$-gal histochemistry was performed as described elsewhere (Sanes, 1986). Histochemical staining was developed at $37^{\circ} \mathrm{C}$ for $2 \mathrm{hr}$ for NB2a and PC12 clones transfected with pCMV/ $\beta$-gal, or for $14-20 \mathrm{hr}$ for PC12 clones transfected with $\mathrm{p} \beta$-gal or $\mathrm{p} \alpha$-CaMKII $/ \beta$-gal. Quantitative kinetic measurements of $\beta$-gal activities in cell extracts were carried out essentially as described elsewhere (Ausubel et al., 1987); assays were initiated by the addition of substrate ( $o$-nitrophenyl- $\beta$-D-galactopyranoside, final concentration $0.4 \mathrm{mg} / \mathrm{ml})$ to a buffer mixture $\left(60 \mathrm{mM} \mathrm{Na}_{2} \mathrm{HPO}_{4}, 40 \mathrm{mM}\right.$ $\mathrm{NaH}_{2} \mathrm{PO}_{4}, 10 \mathrm{mM} \mathrm{KCl}, 1 \mathrm{mM} \mathrm{MgCl}$, and $50 \mathrm{~mm} \beta$-mercaptoethanol), which contained the cell extract. Absorbencies at $420 \mathrm{~nm}$ were measured at $1-3 \mathrm{~min}$ intervals for a total duration of $0.5-2.0 \mathrm{hr}$ (determined by the relative $\beta$-gal activity in individual extracts). $\beta$-Gal kinetic assays were normalized on the basis of the extract protein content using the BCA protein assay (Pierce, Rockford, IL).

$R$ Nase protection assay (RPA). ${ }^{32} \mathrm{P}$-labeled cRNA probes were generated by in vitro transcription (Ausubel et al., 1987). An $\alpha$-CaMKII probe (227 nt) containing $22 \mathrm{nt}$ of coding and $92 \mathrm{nt}$ of adjacent $3^{\prime}$ untranslated sequence of the $\alpha$-CaMKII mRNA was used to detect endogenous $\alpha$-CaMKII mRNA in PC12 cells. The pTri-GAPDH-Rat plasmid (Ambion, Austin, TX) that contains $316 \mathrm{nt}$ of the glyceraldehyde 3-phosphate dehydrogenase gene (Tso et al., 1985) was used to generate a GAPDH probe (434 nt long) using SP6 polymerase. Two cRNA probes were used to analyze the $5^{\prime}$ end(s) of endogenous and/or exogenous $\alpha$-CaMKII mRNAs in PC12 cells and brain. An $\alpha 5^{\prime}$ probe (459 nt long) was generated by in vitro transcription from pGEM-3Zf $(-) / \alpha$-CaMKII plasmid (from Dr. Norma Olson) and contained $60 \mathrm{nt}$ of 5 ' flanking sequence plus the entire $208 \mathrm{nt}$ of exon 1 of the $\alpha$-CaMKII gene (see Fig. $6 C$ ). A second cRNA, designated probe 1 (570 nt long; see Fig. $4 B$ ), contained $181 \mathrm{nt}$ of $5^{\prime}$ flanking sequence plus an additional $109 \mathrm{nt}$ immediately $3^{\prime}$ to the $\alpha$-CaMKII TIS +1 [see Construct I (Olson et al., 1995)].

DNA templates were purified from $1 \%$ agarose gels using the Geneclean Kit (BIO 101). cRNA probes generated by in vitro transcription were purified on $5 \%$ acrylamide denaturing gels, eluted in $2 \mathrm{M}$ ammonium acetate and $1 \%$ SDS $\left(2-4 \mathrm{hr}\right.$ at $\left.37^{\circ} \mathrm{C}\right)$, precipitated in $60 \%$ ethanol, and dissolved in DEPC $\mathrm{dH}_{2} \mathrm{O}$ or hybridization buffer ( $80 \%$ deionized formamide, $0.4 \mathrm{M} \mathrm{NaCl}, 1 \mathrm{~mm}$ EDTA, and $40 \mathrm{~mm}$ PIPES, pH 6.4). Total cellular RNA was purified using RNA Isolator (total RNA isolation reagent; Genosys, The Woodlands, TX); cells attached to tissue-culture plastic were lysed directly in RNA Isolator. Poly $\left(\mathrm{A}^{+}\right) \mathrm{RNA}$ (here referred to as mRNA) was purified by oligo-dT cellulose (Collaborative Biomedical Products) affinity adsorption (FastTrack mRNA Isolation Kit, Invitrogen).

RPAs were performed as described previously (Olson et al., 1995), with the exception that RNase A was replaced with $1 \mathrm{U} / \mathrm{ml}$ RNase T1. RPAs using 3-6 $\mu \mathrm{g}$ of mRNA were performed to detect endogenous $\alpha$-CaMKII mRNA, and 0.1-0.5 $\mu \mathrm{g}$ of mRNA was used to detect GAPDH mRNA in PC12 cells. To detect $\beta$-gal mRNA in recombinant PC12 cells, $12 \mu \mathrm{g}$ of total cellular RNA was used. Protected ${ }^{32} \mathrm{P}$-cRNA fragments were resolved in $6 \%$ acrylamide denaturing gels and analyzed by x-ray film autoradiography.

$P C R$ and reverse transcriptase-PCR (RT-PCR). Genomic DNA used for PCR analyses was purified from PC12 cells and rat brain tissues as described previously (Laird et al., 1991). PCR was performed using the Access RT PCR System (Promega) with $1 \times$ AMV/Tfl reaction buffer, 0.2 mM dNTPs, $1 \mu \mathrm{M}$ upstream and downstream primers, $0.5 \mathrm{~mm} \mathrm{MgSO}_{4}$ (unless indicated otherwise), $0.1 \mathrm{U} / \mu \mathrm{l}$ Tfl DNA polymerase, and $250 \mathrm{ng}$ DNA template (final reaction volume, $50 \mu \mathrm{l}$ ). The reaction was overlaid with $60 \mu \mathrm{l}$ of mineral oil (Sigma) and subjected to the following thermal cycling conditions: $94^{\circ} \mathrm{C}$ for $2 \mathrm{~min}, 40$ cycles at $94^{\circ} \mathrm{C}$ for $30 \mathrm{sec}, 54^{\circ} \mathrm{C}$ for

\begin{tabular}{ll}
\hline \multicolumn{2}{l}{ Table 1. Primers used in PCR and RT-PCR } \\
Primer & Sequence $\left(5^{\prime} \rightarrow 3^{\prime}\right)$ \\
\hline Upstream primer PstI $\left(5^{\prime}\right.$ prim) & CAGTCCTGCAGTATTGTGTA \\
Downstream primer HindI $\left(3^{\prime}\right.$ prim) & CTCTTCCGTGAATCGGTGC \\
$\alpha$-CaMKII-specific primer $(\alpha \mathrm{sp})$ & TGGCAGCATACTCCTGGCCAGCCAGCAC \\
Upstream primer $1(\mathrm{p} 1)$ & GCTACCATCACCTGCACCCGA \\
Upstream primer $2(\mathrm{p} 2)$ & GCCTCGCCTGCCTGCCCAGTG \\
Upstream primer $5(\mathrm{p} 5)$ & GCCCCAAGCTCGTCAATCAA \\
\hline
\end{tabular}

$1 \mathrm{~min}, 68^{\circ} \mathrm{C}$ for $2 \mathrm{~min}$, and finally $68^{\circ} \mathrm{C}$ for $7 \mathrm{~min}$. An RT-PCR downstream primer specific to the $\alpha$-CaMKII mRNA ( $\alpha$ sp; see below) was designed not to hybridize with the $\beta, \gamma$, and $\delta$ mRNA isoforms of CaMKII. RT-PCR was performed with $0.1 \mathrm{U} / \mu \mathrm{l}$ AMV reverse transcriptase using $0.25-1.00 \mu \mathrm{g}$ total cellular RNA or $100 \mathrm{ng}$ mRNA. RT-PCR mixtures were incubated at $48^{\circ} \mathrm{C}$ for $45 \mathrm{~min}$ and then subjected to thermal cycling using PCR conditions, except that each cycle used incubations at $94^{\circ} \mathrm{C}$ for $30 \mathrm{sec}, 60^{\circ} \mathrm{C}$ for $1 \mathrm{~min}$, and $68^{\circ} \mathrm{C}$ for $2 \mathrm{~min}$. Primers used in PCR and RT-PCR are listed in Table 1 (also see Figs. 7, 8).

Autoradiography. Individual bands in autoradiographs were scanned by an imaging densitometer (model GS-670, Bio-Rad, Richmond, CA) and quantitated by the Molecular Analysis program (Bio-Rad).

Statistics. Student's $t$ tests were performed to determine significance values for differences between samples.

\section{RESULTS}

\section{$\alpha$-CaMKII promoter activity in NB2a and PC12 cells}

Transient transfections of murine NB2a cells with $\mathrm{p} \alpha$-CaMKII/ $\beta$-gal containing the $\alpha$-CaMKII gene promoter (Olson et al., 1995 ) showed 9.6-fold higher levels of $\beta$-gal activity relative to a promoterless plasmid (i.e., $\mathrm{p} \beta$-gal) (Table 2 ). In contrast, rat PC12 cells displayed extremely low levels of $\beta$-gal activity after transient transfections with $\mathrm{p} \alpha$-CaMKII $/ \beta$-gal that were only 2.7 -fold greater than $\mathrm{p} \beta$-gal transfected controls (Table 2 ). The absolute values of $\alpha$-CaMKII promoter activities were $\sim 1000$ fold lower in PC12 compared with NB2a cells. The latter result is partially attributable to the lower transfection efficiencies of PC12 compared with NB2a cells. When $\alpha$-CaMKII promoter activity was normalized to CMV promoter activity in each cell line, however, the $\alpha$-CaMKII promoter activity was only 12 fold lower in PC12 cells. CMV/ $\beta$-gal promoter activities were high in both cell lines (Table 2). These results indicated that the $\alpha$-CaMKII promoter expressed little activity in PC12 compared with NB2a cells.

To examine further the very low $\alpha$-CaMKII promoter activity in PC12 cells, NB2a and PC12 cells were transfected with $\mathrm{pCMV} / \beta$ gal, $\mathrm{p} \alpha$-CaMKII $/ \beta$-gal, or $\mathrm{p} \beta$-gal, and stable clones were selected on the basis of NEO (G418) resistance. Eleven NB2a and eight PC12 individual clones were isolated and characterized after transfections with $\mathrm{p} \alpha$-CaMKII/ $\beta$-gal. We changed the method for

Table 2. $\alpha$-CaMKII promoter activity in NB2a and PC12 cells after transient transfections with $\beta$-gal reporter plasmids

\begin{tabular}{lcl} 
Plasmid & NB2a & PC12 \\
\hline pCMV $/ \beta$-gal & $3253.5 \pm 71.7$ & $34.9 \pm 9.2$ \\
$\mathrm{p} \alpha$-CaMKII $/ \beta$-gal & $113.8 \pm 18.0$ & $0.11 \pm 0.02$ \\
$\mathrm{p} \beta$-gal & $11.9 \pm 0.8$ & $0.04 \pm 0.02$
\end{tabular}

Average $\beta$-gal activities $\left(\mathrm{OD}_{420 \mathrm{~nm}} \cdot \mathrm{min}^{-1} \cdot \mathrm{mg}^{-1}\right.$ protein $)$ in extracts from NB2a $(n$ $=2)$ or PC12 cells $(n=4)$ transfected with pCMV/ $\beta$-gal, p $\alpha$-CaMKII $/ \beta$-gal, or the promoterless plasmid $\mathrm{p} \beta$-gal [background activity in mock transfected controls (i.e., no plasmid DNA) was subtracted from each experimental value]. Each value was normalized by the amount of cell extract protein in each assay. 
measuring $\beta$-gal activity to a more sensitive and qualitative histochemical staining method that detected $\beta$-gal activity at the single cell level (see Materials and Methods). Figure $1 A$ displays the results from a representative experiment for recombinant NB2a and $\mathrm{PC} 12$ clones transfected with reporter plasmids containing no promoter (p $\beta$-gal), CMV promoter (pCMV/ $\beta$-gal), or $\alpha$-CaMKII promoter $(\mathrm{p} \alpha-\mathrm{CaMKII} / \beta$-gal). NB2a clones transfected with $\mathrm{p} \beta$ gal displayed very little $\beta$-gal staining (Fig. $1 A 1$ ), whereas clones transfected with $\mathrm{pCMV} / \beta$-gal expressed very high levels of $\beta$-gal staining (Fig. 1A3). NB2a clones transfected with $\mathrm{p} \alpha$-CaMKII/ $\beta$ gal displayed an intermediate level of $\beta$-gal enzymatic staining that was expressed evenly throughout cell bodies in $\sim 80 \%$ of the cells in an individual clone (Fig. 1A2). In contrast, PC12 clones transfected with $\mathrm{p} \alpha$-CaMKII $/ \beta$-gal exhibited barely detectable $\beta$-gal staining; only a few PC12 cells (approximately 1 out of 10 ) displayed very low $\beta$-gal staining, as revealed by blue dots in their cytoplasm (Fig. 1A5).

To evaluate better the $\beta$-gal activity in individual clones, the intensity of blue-staining foci in a single cell was graded qualitatively on a scale from 0 to 10 (300-400 cells/plate were analyzed); this score was then multiplied by the percentage of all cells that were stained after each transfection. This product estimates the level of $\beta$-gal staining for each clone. The products for NB2a and $\mathrm{PC} 12$ clones transfected with $\mathrm{pCMV} / \beta$-gal were multiplied by 10 -fold because their histochemical staining was developed only one tenth the time compared with clones transfected with $\mathrm{p} \beta$-gal or $\mathrm{p} \alpha$-CaMKII $/ \beta$-gal (see Materials and Methods). NB2a clones transfected with $\mathrm{p} \alpha$-CaMKII $/ \beta$-gal $(n=11)$ exhibited an average $\beta$-gal staining level of $33 \pm 7$. In contrast, PC12 clones transfected with $\mathrm{p} \alpha$-CaMKII/ $\beta$-gal $(n=8)$ exhibited weak staining that averaged $1.0 \pm 0.4$ under standard growth conditions. Because the staining intensity of these PC12 clones was so near background, we used the nonspecific transcriptional activator sodium butyrate (NaBut) to activate transcription by inhibiting histone acetylation (Arts et al., 1995). NaBut treatment of all eight PC12 clones transfected with $\mathrm{p} \alpha$-CaMKII $/ \beta$-gal resulted in moderate $\beta$-gal staining in each clone, with an average value of $5.1 \pm 1.1$. This fivefold increase indicated that all eight PC12 clones had integrated the $\mathrm{p} \alpha$-CaMKII $/ \beta$-gal, although their $\beta$-gal expression levels in the absence of NaBut were very low. In contrast, stable PC12 clones transfected with $\mathrm{p} \beta$-gal $(n=7)$ displayed no significant $\beta$-gal staining (average value $=0.1 \pm$ 0.1 ) (Fig. 1A4), which was not affected by NaBut treatment (data not shown).

PC12 $(n=6)$ and NB2a $(n=12)$ clones were isolated after stable transfections with $\mathrm{pCMV} / \beta$-gal to compare with results from transient transfections. The CMV promoter is very active in PC12 cells (Donis et al., 1993). All twelve NB2a clones transfected with $\mathrm{pCMV} / \beta$-gal exhibited substantial $\beta$-gal staining (average value $=68 \pm 9)($ Fig. $1 \mathrm{A3})$, whereas the six PC12 clones displayed an even greater average staining of $92 \pm 5$ under standard culture conditions (Fig. 1A6) (NaBut treatment did not significantly increase $\beta$-gal staining in these PC12 clones). When $\alpha$-CaMKII promoter activities in all clones were normalized by CMV promoter activity, values were $\sim 45$ times lower in PC12 versus NB2a clones. These results provided additional proof that $\alpha$-CaMKII promoter activity in PC12 cells is very low under standard culture conditions; the low $\alpha$-CaMKII promoter activity was significant because the CMV promoter appeared more active in PC12 compared with NB2a clones.

\section{RA stimulates $\alpha$-CaMKII promoter activity in PC12 cells}

\section{Analysis of $\beta$-gal enzyme expression levels}

The apparent suppression of $\alpha$-CaMKII promoter activity in PC12 cells, and its upregulation in NB2a cells, may be analogous to the neuron-type specific and developmental expression of the endogenous $\alpha$-CaMKII gene in vivo. To examine the very low expression of the $\alpha$-CaMKII promoter in PC12 cells, we tested various factors that induce a neuron-like differentiation of PC12 cells (e.g., NGF) (Tischler and Greene, 1975; Tischler et al., 1977) to see whether they stimulated $\alpha$-CaMKII promoter activity. We added various factors to the standard culture medium, including 8-bromo-cAMP (1 mM), dibutyl-cAMP $(50 \mu \mathrm{M})$, all-trans RA $(25 \mu \mathrm{M})$, or NGF (40 nM). In addition, $\mathrm{PC} 12$ cells were treated with $\mathrm{KCl}(55 \mathrm{~mm})$, the protein kinase inhibitors H-89 $(2 \mu \mathrm{M})$ or KN-62 $(10 \mu \mathrm{M})$, colchicine $(0.83 \mathrm{~mm})$, and NEO (5 $\mathrm{mm})$ to examine whether events involved in intracellular signaling pathways activated by membrane depolarization or mediated by protein kinase activities $(\mathrm{H}-89$, KN62 , and $\mathrm{KCl}$ ) or the cell growth cycle (colchicine) could stimulate the $\alpha$-CaMKII promoter activity. Mixed PC12 clones (see Materials and Methods) stably transfected with $\mathrm{p} \alpha$-CaMKII/ $\beta$ gal, $\mathrm{pCMV} / \beta$-gal, or $\mathrm{p} \beta$-gal were used for these experiments. Of all the agents tested, only cAMP, NGF, and RA readily induced neurite extension and cell differentiation. Among these agents, only RA stimulated $\alpha$-CaMKII promoter activity in PC12 cells. Figure $1 B$ shows the effects of adding RA to the same populations of PC12 mixed clones. RA $(25 \mu \mathrm{M})$ stimulated $\beta$-gal expression only in $\alpha$-CAMKII $/ \beta$-gal PC12 mixed clones (Fig. $1 B 5$ vs $1 B 2$ ) and had no apparent effect on pCMV/ $\beta$-gal (Fig. $1 B 6$ vs $1 B 3$ ) or $\mathrm{p} \beta$-gal mixed clones (Fig. $1 B 4$ vs $1 B 1)$. Quantitative $\beta$-gal enzymatic assays showed that RA increased $\mathrm{p} \alpha$-CaMKII $\beta$-gal expression in $\mathrm{PC} 12$ mixed clones by $124 \%$ compared with the same mixed clones cultured in the absence of RA (Fig. 2). This stimulatory effect was significant $(p<0.05)$ compared with the effects of RA on $\mathrm{p} \beta$-gal $\mathrm{PC} 12$ mixed clones (39\% increase, Fig. 2). RA increased CMV promoter activity to a small degree (24\%), which was not significantly different from the effects of RA on $\mathrm{p} \beta$-gal PC12 clones (Fig. 2). These data indicate that RA selectively stimulated the $\alpha$-CaMKII promoter activity in PC12 cells compared with the CMV promoter.

To examine whether the action of RA on $\alpha$-CaMKII promoter activity was direct or indirect, we determined the time course of RA stimulation on $\beta$-gal expression using $\beta$-gal histochemical staining. Results with PC12 mixed clones showed that longer RA treatments (from 2 hr to $5 \mathrm{~d}$ ) correlated with higher $\beta$-gal activity (data not shown). To examine more accurately the stimulatory effect of RA on $\alpha$-CaMKII promoter activity, individual PC12 clones were treated with RA for 4 and $12 \mathrm{hr}$ and for 1, 3, and 5.2 d, and assayed by histochemical staining. The shortest time at which RA significantly stimulated $\alpha$-CaMKII promoter activity was $12 \mathrm{hr}$ (data not shown). The time course of stimulation by RA of $\alpha$-CaMKII $/ \beta$-gal expression for two representative clones (B4 and $\mathrm{C} 1$ ) was measured by histochemical staining (Fig. $1 C 1-6$ ) or $\beta$-gal enzymatic assays (Fig. 3). The time at which RA maximally stimulated $\alpha$-CaMKII promoter activity was different between these clones. B4 displayed the highest stimulation after $5 \mathrm{~d}$, whereas $\mathrm{C} 1$ displayed the greatest stimulation by day 1 . These results suggested that RA may act through an indirect pathway and that $12-24 \mathrm{hr}$ is required for it to exert its effects. Addition- 

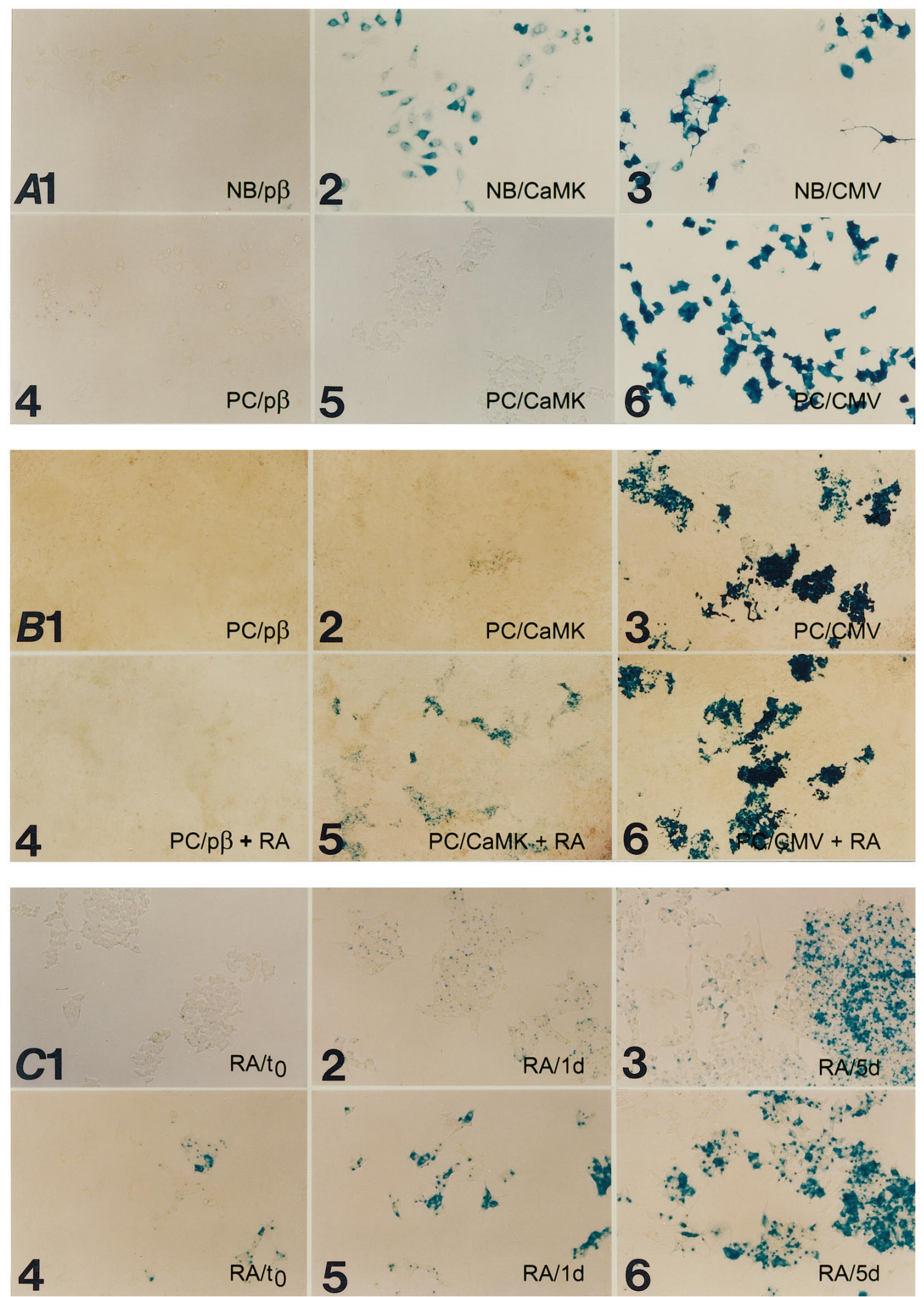

Figure 1. In situ histochemical staining of $\beta$-gal activity in transfected cells. $A, \beta$-gal staining in NB2a $(N B, A 1-A 3)$ and PC12 (PC, $A 4-A 6)$ clones stably transfected with different reporter plasmids containing no promoter ( $p \beta, A 1$ and $A 4), \alpha$-CaMKII promoter $(C a M K ; A 2$ and $A 5)$, or CMV promoter (CMV, $A 3$ and $A 6)$. $B$, In situ histochemical staining of $\beta$-gal activity in PC12 mixed clones stably transfected with the promoterless p $\beta$-gal $(p \beta, B 1$ and $B 4)$, $\mathrm{p} \alpha$-CaMKII/ $\beta$-gal $(C a M K ; B 2$ and B5), or pCMV/ $\beta$-gal $(C M V ; B 3$ and $B 6)$. Cells were grown for $5 \mathrm{~d}$ in complete medium (B1-B3) or in medium plus $25 \mu \mathrm{M}$ RA (B4-B6). C, In situ histochemical staining of $\beta$-gal activity in PC12 clones $\mathrm{B}_{4}(C 1-C 3)$ and $\mathrm{C}_{1}(C 4-C 6)$ transfected with p $\alpha$-CaMKII/ $\beta$-gal. Cells were grown in medium containing $25 \mu \mathrm{M}$ RA for $0 \mathrm{hr}(C 1$ and $C 4), 24 \mathrm{hr}(C 2$ and $C 5)$, or $5 \mathrm{~d}(C 3$ and $C 6)$. Bright-field micrographs were photographed with a Nikon Diaphot inverted microscope $(\sim 200 \times)$. 


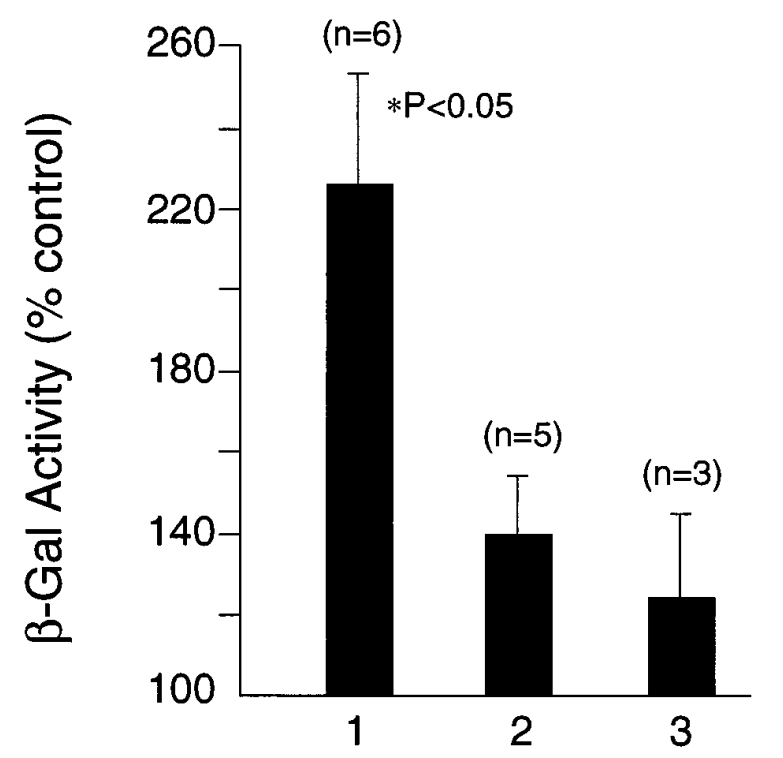

Figure 2. RA selectively stimulates $\alpha$-CaMKII promoter activity in PC12 mixed clones. Average $\beta$-gal activities \pm SEM in PC12 clones stimulated with $25 \mu \mathrm{M}$ RA for $5 \mathrm{~d}$. Values are normalized and represent the ratio of $\beta$-gal activities in cultures stimulated with RA versus ethanol controls. Stable clones were obtained with different reporter constructs: (1) p $\alpha$ $\mathrm{CaMKII} / \beta$-gal, (2) $\mathrm{pCMV} / \beta$-gal, or (3) the promoterless $\mathrm{p} \beta$-gal.

ally, the mechanism by which RA acts in each individual clone might not be identical because of the possibility that the genomic integration of $\mathrm{p} \alpha$-CaMKII/ $\beta$-gal may vary among clones.

\section{Effects of $\alpha$-CaMKII promoter activity on mRNA levels}

Because assays of $\beta$-gal activity are an indirect measure of promoter activity, we examined $\alpha$-CaMKII mRNA levels using RNase protection assays. A cRNA probe (probe 1) was hybridized to total cellular RNA prepared from individual PC12 clones (B4 and $\mathrm{C} 1)$ after treatment with RA $(25 \mu \mathrm{M})$ or ethanol $(0.125 \%)$ for $3 \mathrm{~d}$ (Fig. 4). Probe 1 is specific to a sequence contained in the 5' region of the $\alpha$-CaMKII gene (Fig. $4 B$ ). Probe 1 produced a protected fragment of $109 \mathrm{nt}$ (Fig. 4A). Autoradiographic results were quantitated by scanning densitometry. RA selectively increased the levels of the $109 \mathrm{nt}$ fragment in both B4 (twofold) and

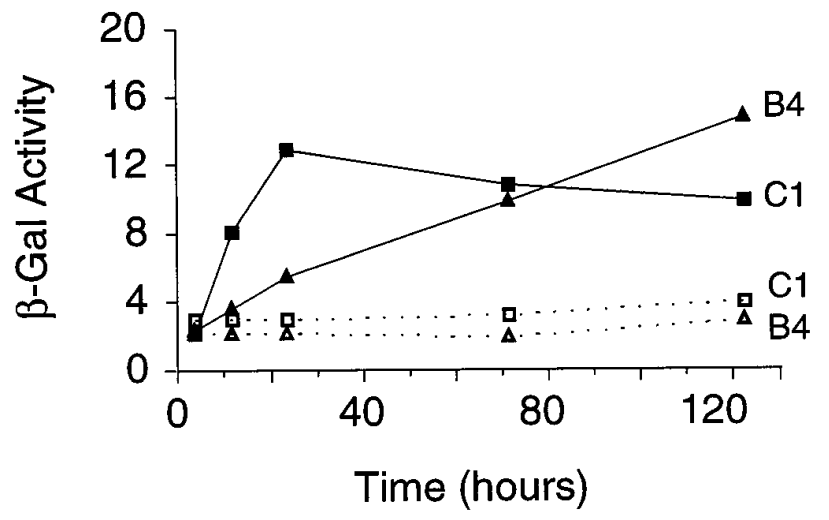

Figure 3. RA stimulates $\alpha$-CaMKII promoter in a time-dependent manner. $\beta$-Gal activities $\left(\mathrm{OD}_{420 \mathrm{~nm}} \cdot \mathrm{min}^{-1} \cdot \mathrm{mg}\right.$ protein $\left.{ }^{-1}\right)$ of two stable PC12 clones (B4 and $C 1)$ transfected with $\alpha$-CaMKII $/ \beta$-gal. RA ( $25 \mu \mathrm{M}$; solid lines) was added at $t=0$, and equivalent PC12 cultures were harvested 4 and $12 \mathrm{hr}$ and 1,3 , and $5.2 \mathrm{~d}$ later; control cultures were treated with ethanol (dotted lines).
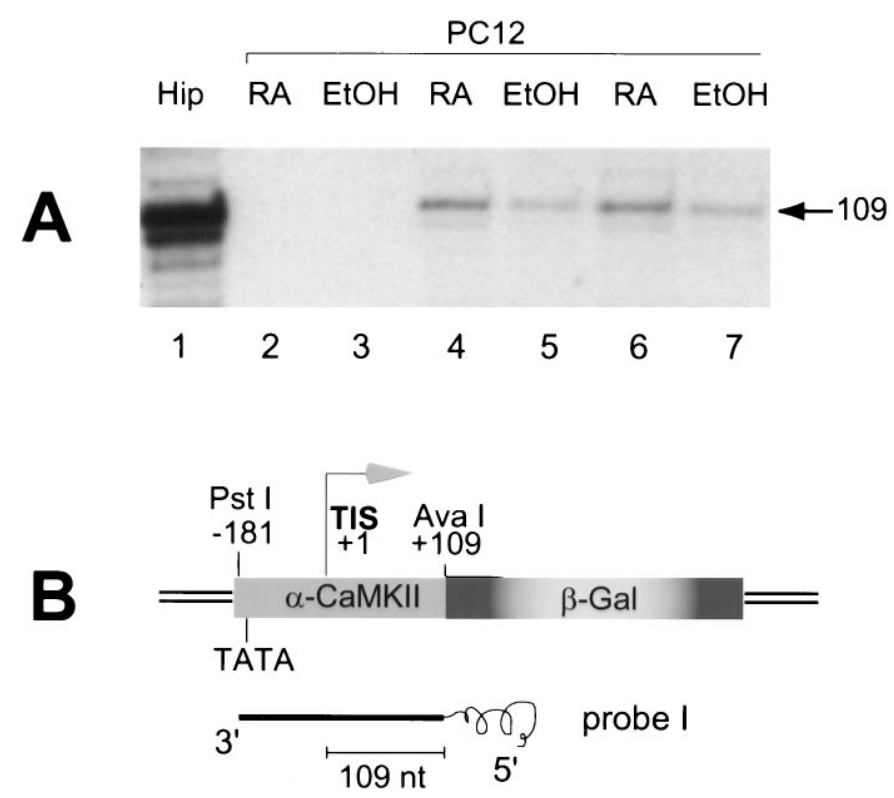

Figure 4. RA stimulates $\alpha$-CaMKII promoter activity in PC12 cell clones (B4 and $\mathrm{C} 1$ ) as measured by RNase protection assays (RPA). $A$, A cRNA probe (probe 1), specific to the $5^{\prime}$ region of the $\alpha$-CaMKII gene, was hybridized to $2 \mu \mathrm{g}$ of total cellular RNA from hippocampus (lane 1), $3 \mu \mathrm{g}$ of mRNA from untransfected PC12 cells (lanes 2 and 3), or $6 \mu \mathrm{g}$ of total cellular RNA from PC12 clones B4 (lanes 4 and 5) or C1 (lanes 6 and 7); cultures were treated with $25 \mu \mathrm{M}$ RA (lanes 2, 4, and 6) or ethanol $(0.125 \%$; lanes 3,5 , and 7$)$ for $5 \mathrm{~d}$ (lanes 2 and 3 ) or $3 \mathrm{~d}$ (lanes $4-7)$. A protected fragment in $109 \mathrm{nt}$ was generated. $B$, A map of $\mathrm{p} \alpha$-CaMKII $/ \beta$ gal showing the homologous region between probe 1 and $\alpha$-CaMKII mRNA (double lines indicate sequences of the $\mathrm{pRC/CMV}$ vector, the single thick line represents the homologous region of probe 1 , and the curved line shows the nonhomologous region of probe 1).

C1 (1.5-fold) clones relative to ethanol controls. Results in Figure $4 A$ are consistent with results from $\beta$-gal assays (Figs. 2,3 ). The $109 \mathrm{nt}$ fragment corresponds to a TIS for the exogenous $\alpha$-CaMKII gene in PC12 cells, which is similar in location to TIS $_{+1}$ for the gene in rat hippocampus (Fig. 4A, lane 1) (Olson et al., 1995). These results suggest that the effects of RA on $\alpha$-CaMKII promoter activity in PC12 cells seems to regulate transcription at a TIS analogous to the endogenous TIS $_{+1}$ in rat hippocampus.

\section{RA stimulates transcription of endogenous $\alpha$-CaMKII gene}

If the stimulatory effect of RA on the transfected $\alpha$-CaMKII $/ \beta$-gal reporter gene has physiological significance, RA should also produce a similar effect on the $\alpha$-CaMKII gene in untransfected PC12 cells. Untransfected PC12 cells were treated with RA (25 $\mu \mathrm{M})$ for different periods of time. After RA treatment for $5 \mathrm{~d}$, neurite outgrowth from PC12 cells was enhanced both in number and length when compared with ethanol controls or standard growth conditions (Fig. $5 A$ ), indicating that PC12 cell morphology became more neuron-like. Previous experiments showed that endogenous CaMKII levels are too low in PC12 cells to be detected by Western blots or in situ immunohistochemistry (Massé et al., 1993). Therefore, $\mathrm{PC} 12$ cells were treated with $\mathrm{RA}$, and $\operatorname{poly}\left(\mathrm{A}^{+}\right)$ RNA was purified from the cells and analyzed by a sensitive RPA (see Materials and Methods). RPAs were performed using high specific activity cRNA probes $(800 \mathrm{Ci} / \mathrm{mmol})$, which would generate a protected fragment of $115 \mathrm{nt}$ corresponding to the $3^{\prime}$ region of the $\alpha$-CaMKII mRNA (Fig. 5B). RA treatments for $6 \mathrm{hr}$, 


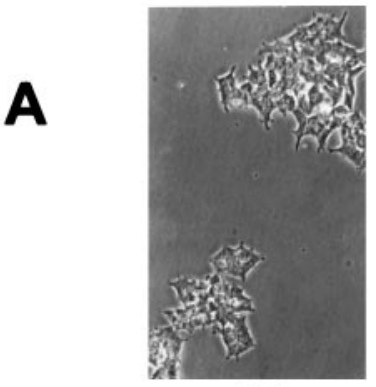

Std

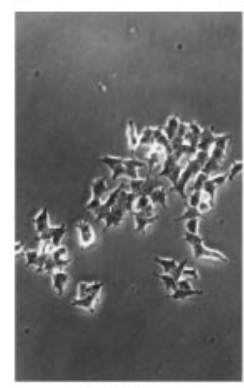

EtOH

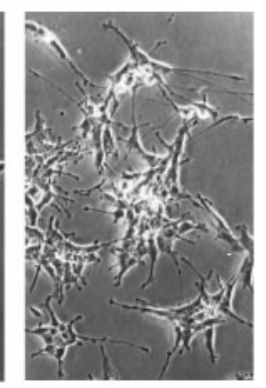

RA
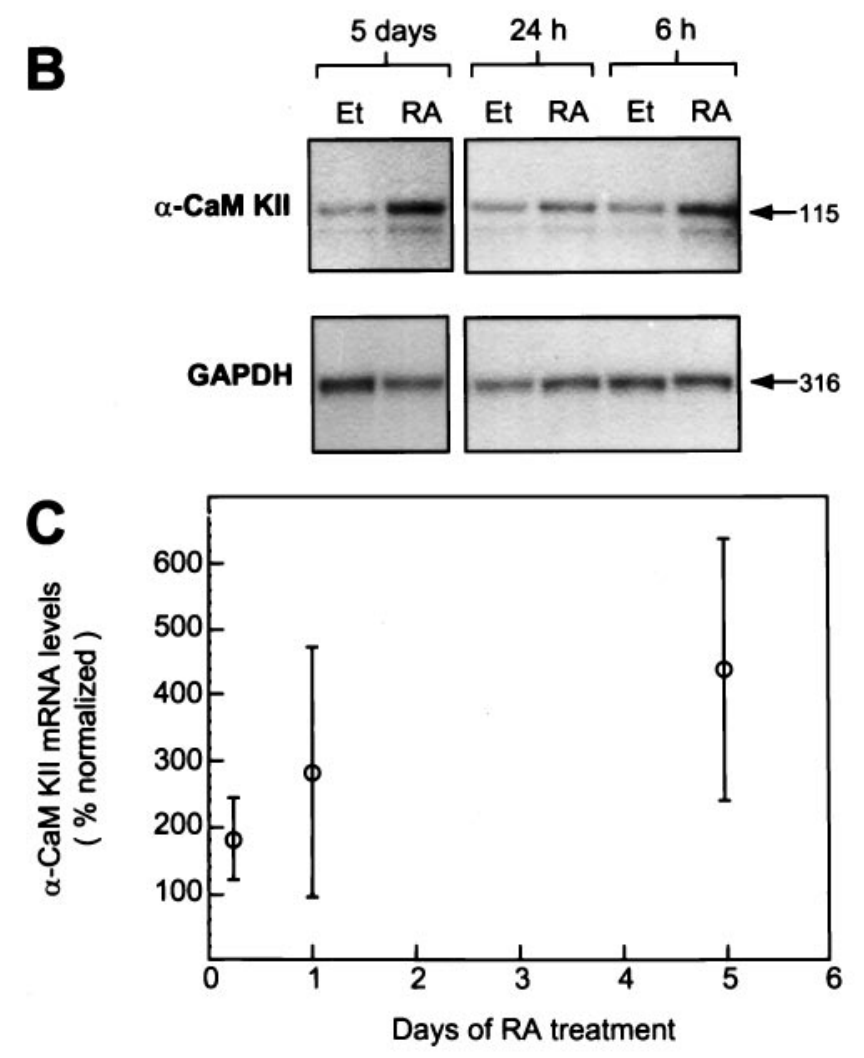

Figure 5. Effects of RA on normal PC12 cells. A, Representative micrographs of PCI 2 cells cultured for $5 \mathrm{~d}$ in complete medium $(S t d)$, in medium plus $25 \mu \mathrm{M} \mathrm{RA}$, or in medium plus $0.125 \%$ ethanol. $B$, RNase protection assays from a representative experiment with normal PC12 cells cultured in complete medium plus RA $(25 \mu \mathrm{M})$ or $0.125 \%$ ethanol $(E t)$ for 6 and 24 $\mathrm{hr}$ or $5 \mathrm{~d}$. mRNA was purified from cultures and hybridized (4 or $0.5 \mu \mathrm{g})$ to $\alpha$-CaMKII or GAPDH probes, respectively; after digestion by RNase T1, protected fragments of $115 \mathrm{nt}$ for the $\alpha$-CaMKII probe and $316 \mathrm{nt}$ for the GAPDH probe were detected. $C$, Average effects of RA versus ethanol on $\alpha$-CaMKII mRNA levels in cultures treated for $6 \mathrm{hr}(n=2)$, $24 \mathrm{hr}(n=3)$, and $5 \mathrm{~d}(n=4)$; values are normalized by the amount of GAPDH mRNA in each culture.

$24 \mathrm{hr}$, and $5 \mathrm{~d}$ all increased $\alpha$-CaMKII mRNA levels (Fig. 5B). When RPA results were normalized to the levels of GAPDH mRNA in each sample, $5 \mathrm{~d}$ RA treatments gave the greatest increase in $\alpha$-CaMKII mRNA levels (4.4-fold) compared with ethanol controls (Fig. 5C). RA treatments for 6 and $24 \mathrm{hr}$ resulted in increases in mRNA levels of 1.8- and 2.8-fold, respectively. These results showed that RA treatments stimulated differentiation and neurite extension and increased endogenous $\alpha$-CaMKII mRNA levels in untransfected PC12 cells.

\section{Analysis of transcription initiation sites of $\alpha$-CaMKII gene in PC12 cells and rat brain}

The results above show that RA stimulates $\alpha$-CaMKII gene expression approximately fourfold in PC12 cells; however, this stimulation is considerably less than the 20 -fold increase in $\alpha$-CaMKII expression observed during postnatal brain development (Kelly and Vernon, 1985). We therefore explored the possibility that the TIS for the endogenous $\alpha$-CaMKII gene may be different between PC12 cells and rat brain, and this may contribute to its greatly variant expression among different cell types.

We examined the TIS for the endogenous $\alpha$-CaMKII gene using a cRNA probe $\left(\alpha 5^{\prime}\right.$ probe, Fig. $6 C$ ) complementary to its first exon and containing the TIS $_{+1}$ plus an additional $61 \mathrm{nt}$ of $5^{\prime}$ flanking genomic sequence. A 208 nt cRNA fragment from the $\alpha 5^{\prime}$ probe was protected by RNA from rat forebrain, hippocampus, and cerebellum (Fig. $6 A$ ). The length of this protected fragment corresponds to TIS $_{+1}$ in rat forebrain and is consistent with previous results (Sunyer and Sahyoun, 1990; Olson et al., 1995). Surprisingly, however, mRNA from PC12 cells protected only a $62 \mathrm{nt}$ fragment from the $\alpha 5^{\prime}$ probe (Fig. $6 A, B$ ). This $62 \mathrm{nt}$ fragment was also generated with RNA from rat cerebellum but was not apparent in assays using forebrain or hippocampal RNAs (Fig. 6A). This 62 nt fragment could be detected only in hippocampus/forebrain RPAs after autoradiographic exposures that were 40 times longer than comparable RPAs carried out with PC12 RNA (results not shown). This $62 \mathrm{nt}$ fragment corresponds to an unusual TIS ${ }_{+148}$ located very near the ATG translation start codon $( \pm 2 \mathrm{nt})$ in the $\alpha$-CaMKII mRNA. In addition, RA treatments of 1 or $5 \mathrm{~d}$ increased levels of $\alpha$-CaMKII mRNA in PC12 cells by transcription at TIS $_{+148}$ (Fig. $6 B$, lanes $4-7$ ), without any detectable transcription at $\mathrm{TIS}_{+1}$. Another ${ }^{32} \mathrm{P}-\mathrm{cRNA}$ (probe 1, Fig. $4 B$ ) was used in RPAs with RNA from PC12 cells and rat hippocampus. A protected fragment of $109 \mathrm{nt}$ corresponding to $\mathrm{TIS}_{+1}$ was generated with hippocampal RNA (Fig. 4A, lane 1) but not PC12 RNA (Fig. 4A, lanes 2 and 3). These results indicate that transcription initiation of $\alpha$-CaMKII mRNA in untransfected PC12 cells is at the unusual TIS $_{+148}$ and not at the TIS ${ }_{+1}$ observed in forebrain and hippocampus. The unusual TIS Ti14 $_{+1}$ is also the predominant TIS in rat cerebellum (Fig. 6A).

To determine whether the unusual TIS $_{+148}$ in PC12 was attributable to an altered $5^{\prime}$ flanking region of the $\alpha$-CaMKII gene in PC12 cells, PCRs were performed. PCR used a pair of primers (5' prim and 3' prim; Table 1) complementary to the 5' flanking region of the $\alpha$-CaMKII gene, from 5' of the TATA element (188 $\mathrm{nt} 5^{\prime}$ of the endogenous TIS $_{+1}$ in hippocampus) to $3^{\prime}$ of the ATG translation start codon (182 nt $3^{\prime}$ of the endogenous TIS $_{+1}$ in hippocampus). PCR analysis of genomic DNA from rat PC12 cells, rat hippocampus and cerebellum, and the plasmid [pGEM$3 \mathrm{Zf}(-) / \alpha$-CaMKII] used to synthesize the $\alpha 5^{\prime}$ probe (see Material and Methods) showed that all DNAs generated the same $369 \mathrm{nt}$ PCR product (Fig. 7). This PCR product corresponds to the predicted length based on the sequence of the rat $\alpha$-CaMKII gene (Olson et al., 1995). This result indicates that the 5' region of the $\alpha$-CaMKII gene in PC12 cells is similar to that in rat brain.

To confirm the identity of the unusual TIS ${ }_{+148}$ in PC12 cells on the basis of RPA results (Fig. 6), we performed RT-PCR with RNA samples from hippocampus, cerebellum, and PC12 cells. Because there is a high degree of homology among the coding regions of the $\alpha, \beta, \gamma$ and $\delta$ isoforms of rat brain CaMKII (Tobimatsu and Fujisawa, 1989), we selected a sequence for the $3^{\prime}$ RT-primer ( $\alpha$ sp; Table 1$)$ that encodes amino acids $34-43$. The 


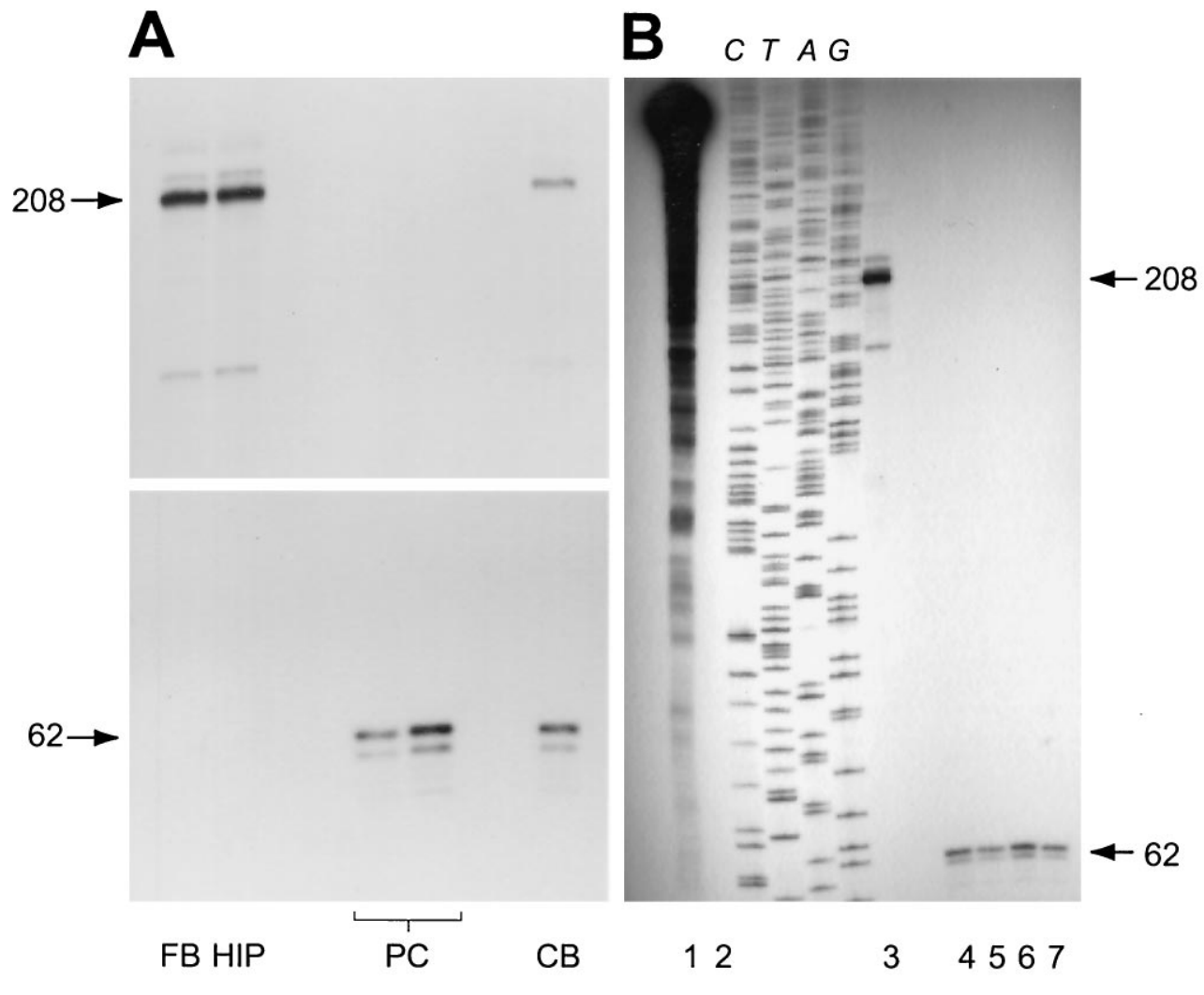

Figure 6. RPA analysis of transcription initiation sites $(T I S)$ in rat hippocampus $(H I P)$, forebrain $(F B)$, cerebellum $(C B)$, and $\mathrm{PC} 12$ cells $(P C)$. A probe specific to the $5^{\prime}$ region of the $\alpha$-CaMKII gene $\left(\alpha 5^{\prime}\right.$ probe) was hybridized to total cellular RNA $[4 \mu \mathrm{g}$ from $F B$ and $H I P, 20 \mu \mathrm{g}$ from $C B$, or $4 \mu \mathrm{g}$ of poly $\left(\mathrm{A}^{+}\right)$mRNA from $\left.P C\right]$ and then digested with RNase T1. $A$, Expanded views of gels showing the two major protected cRNA fragments (208 and $62 \mathrm{nt}$ ) observed in RPA. $B$, An entire gel of a representative RPA experiment with RNA from $F B$ (lane 3), or $P C$ treated with RA (lanes 4 and 6) or EtOH (lanes 5 and 7) for $24 \mathrm{hr}$ (lanes 4 and 5) or $5 \mathrm{~d}$ (lanes 6 and 7); control RPAs containing the $\alpha 5^{\prime}$ probe with (lane 2) or without (lane 1) RNase T1 are shown. An M13Mp18 sequencing ladder is shown (lanes $C, T, A$, and $G$ ); the sizes of protected fragments are indicated in nucleotides. $C, \alpha$-CaMKII gene structure and homology with the $\alpha 5^{\prime}$ probe (thick line indicates homologous region; curved line shows the nonhomologous region). Autoradiographic exposures were for $14-16 \mathrm{hr}$ $\left(-80^{\circ} \mathrm{C}\right.$ with intensifying screens).

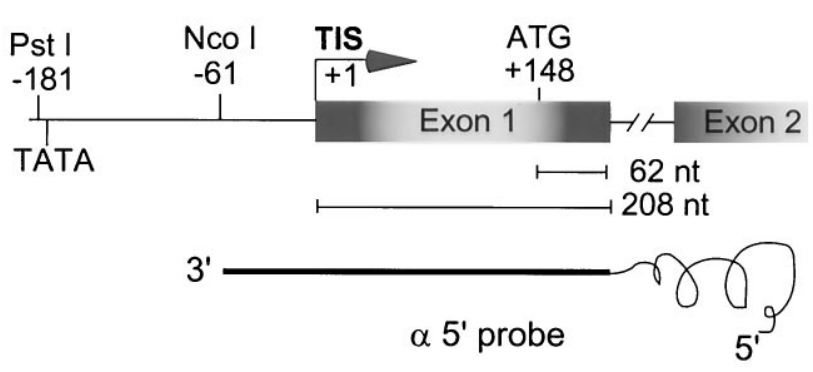

first three amino acids in this sequence (Val-Leu-Ala) and the corresponding nine nucleotides of the 3' RT-primer $\alpha$ sp are specific to the $\alpha$-isoform of CaMKII. Two 5' PCR primers (p1 and p2; Table 1) were designed to flank the ATG translation start codon and are separated by only $9 \mathrm{nt}$. A third 5' PCR primer (p5; Table 1) is situated just $4 \mathrm{nt} 3^{\prime}$ of the endogenous TIS $_{+1}$ in hippocampus (Fig. 8B). RT-PCR with these three PCR primers should determine the $5^{\prime}$ end of endogenous $\alpha$-CaMKII mRNA in PC1 2 cells. RT-PCR using $\alpha$ sp (i.e., $\alpha$-CaMKII-specific primer) together with $\mathrm{p} 1, \mathrm{p} 2$, or $\mathrm{p} 5$ generated the expected RT-PCR products of 122,149 , or $266 \mathrm{nt}$ using hippocampal RNA, respectively (Fig. $8 A$, lanes 1,2 , and 8 ). These results are consistent with the $5^{\prime}$ end of the $\alpha$-CaMKII mRNA being located 5' of p5 (Fig. $8 B$ ), and they support our RPA results (Fig. 6). When cerebellum RNA was used, RT-PCR with 1 and $\alpha$ sp generated the expected $122 \mathrm{nt}$ product (Fig. 8A, lane 3); in contrast, RT-PCR with $\mathrm{p} 2$ and $\alpha$ sp consistently generated less of the expected $149 \mathrm{nt}$ product (Fig. 8A, lane 4). In addition, RT-PCR using cerebellum RNA with $\mathrm{p} 5$ and $\alpha \mathrm{sp}$ generated a 266 nt product, but only at high $\mathrm{MgSO}_{4}$ concentrations (1-3 mM), which greatly increased the appearance of background RT-PCR bands (Fig. 8A, lane 13). In general, the optimal $\left[\mathrm{MgSO}_{4}\right]$ for RT-PCR analyses was $0.5 \mathrm{~mm}$, regardless of the source of RNA used in each reaction (results not shown). These results suggest that the major population of mRNAs in cerebellum have a TIS between $\mathrm{p} 1$ and $\mathrm{p} 2$, with a more minor TIS being located 5' to p5 (i.e., TIS $_{+1}$ ). These results are consistent with the RPA results described above (Fig. 6), although it seemed that $\mathrm{p} 5$ was less efficient in generating RT-PCR products relative to $\mathrm{p} 1$ or $\mathrm{p} 2$, which may be attributable to the melting temperature for $\mathrm{p} 5\left(69^{\circ} \mathrm{C}\right)$ being lower than that of $\mathrm{p} 2\left(79^{\circ} \mathrm{C}\right)$.

RT-PCR analysis of poly $\left(\mathrm{A}^{+}\right)$RNA produced different results from PC12 cells compared with brain. RT-PCR with PC12 mRNA generated a detectable product only when $\mathrm{p} 1$ and $\alpha$ sp primers were used (Fig. 8A, lane 5); no detectable specific products were observed with $\alpha \mathrm{sp}$ and either $\mathrm{p} 2$ (Fig. 8A, lanes 6 and 7) or p5 (lanes 10, 12, and 14), even though the generation of specific RT-PCR products appeared optimal at a $\left[\mathrm{MgSO}_{4}\right]$ of $0.5 \mathrm{~mm}$. These results indicate that the $5^{\prime}$ end of the endogenous $\alpha$-CaMKII mRNA in PC12 cells is located between p1 and p2, which is consistent with the RPA results described above, and places the unusual $\mathrm{TIS}_{+148}$ for PC12 cells very near the ATG translation start codon (Fig. 6). 


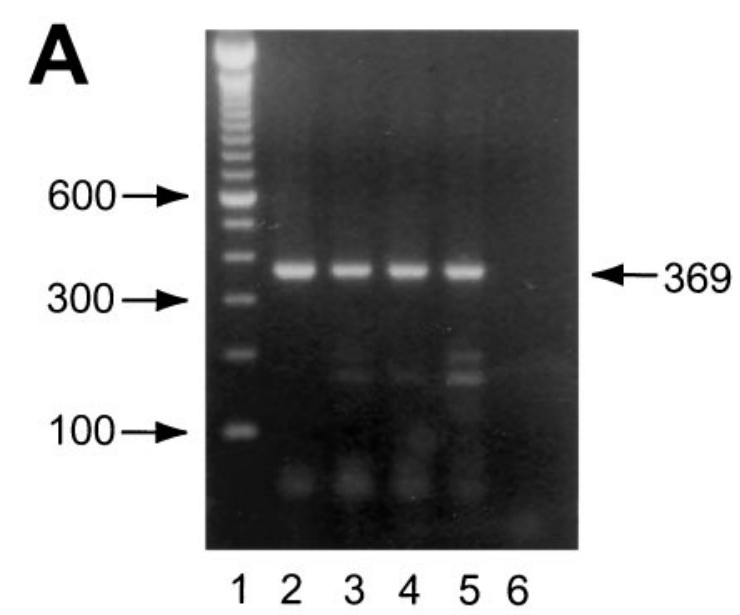

B

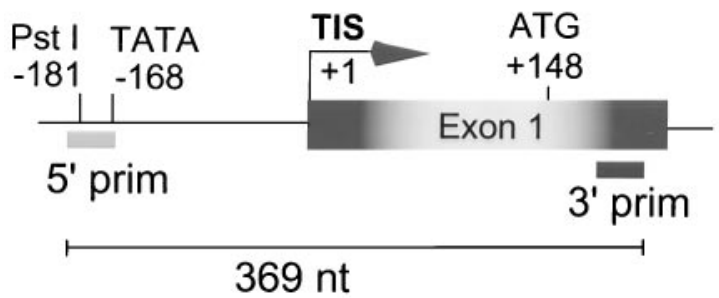

Figure 7. PCR analysis of the $5^{\prime}$ region of the $\alpha$-CaM KIl gene in rat brain and PC12 cells. $A$, PCR was carried out with $3^{\prime}\left(3^{\prime}\right.$ prim) and $5^{\prime}\left(5^{\prime}\right.$ prim) primers (Table 1) using $250 \mathrm{ng}$ genomic DNA from hippocampus (lane 2), cerebellum (lane 3), or PC12 cells (lane 4). A plasmid [pGEM$3 \mathrm{Zf}(-) / \alpha$-CaMKII] ( $1 \mathrm{ng}$ ) containing the $5^{\prime}$ sequence of the rat $\alpha$-CaMKII gene was used as a positive control (lane 5); PCR with rat DNA but without Tfl DNA polymerase was performed as a negative control (lane 6). The predicted length of the $\alpha$-CaMKIl-specific PCR product is $369 \mathrm{nt} . B$, Partial map of $\alpha$-CaMKII gene structure showing PCR primers.

Although the genomic sequence of the $\alpha$-CaMKII gene is indistinguishable between PC12 cells and rat brain tissues when examined by PCR (Fig. 7), there seems to be a difference in the mRNA sequences between PC12 cells and rat brain (Fig. 8 A, lane 5 vs lanes 1 and 3 ) in that the sequence located between 1 and $\alpha \mathrm{sp}$ is $\sim 50 \mathrm{nt}$ longer in PC12 cells compared with hippocampus or cerebellum. This suggests that an additional $50 \mathrm{nt}$ exon is expressed in PC12 cells, and that $\alpha$-CaMKII in PC12 cells is $\sim 17$ amino acids larger than the $\alpha$-CaMKII in rat brain (i.e., the PC12 $\alpha$-CaMKII is $\sim 2000 \mathrm{Da}$ larger). This is consistent with previous results showing that rat brain $\alpha$-CaMKII is $\sim 51,000 \mathrm{Da}$, and $\alpha$-CaMKII in PC12 cells is $\sim 53,000 \mathrm{Da}$ (Nose et al., 1985).

\section{DISCUSSION}

Previous studies have shown that the expression of $\alpha$-CaMKII mRNA and protein are very high in certain CNS neurons (e.g., hippocampal pyramidal neurons) but very low in others (e.g., cerebellar granule cells) (Kelly and Cotman, 1981; Fukunaga et al., 1988; Scholz et al., 1988; Walaas et al., 1988; Burgin et al., 1990). The expression of $\alpha$-CaMKII is extremely low or undetectable in non-neuronal cells (Scholz et al., 1988; Hanson and Schulman, 1992), and during postnatal brain development its expression increases 20-fold and remains high in the adult (Kelly and Vernon, 1985; Burgin et al., 1990).

The $\alpha$-CaMKII promoter is active in mouse NB2a cells but not in fibroblast cell lines (Olson et al., 1995), suggesting that it may contain cell-type specific regulatory elements. In contrast, the endogenous $\alpha$-CaMKII expressed in PC12 cells is virtually undetectable on the basis of Western blot and immunohistochemical analyses (Massé et al., 1993). This result was unexpected, because PC12 cells share many properties with sympathetic neurons, such as the synthesis and release of catecholamines (Greene and Tischler, 1983) and the expression of cholinergic markers (Haycock et al., 1982; Greene and Tischler, 1983; Scheibe et al., 1991). Sympathetic neurons also express CaMKII activity (Matthies et al., 1987). CaMKII in PC12 cells is similar to rat brain on the basis of its substrate specificity (e.g., site-specific phosphorylation of MAP-2) and phosphopeptide fingerprints of the autophosphorylated CaMKII (Nose et al., 1985). Because of the very low activity of the $\alpha$-CaMKII promoter in PC12 cells, we used them to examine the regulation of $\alpha$-CaMKII gene expression in a neuronlike cell line.

Transient transfections of $\mathrm{PC} 12$ and NB2a cells showed that $\alpha$-CaMKII promoter activity, as measured by $\beta$-gal reporter enzymatic activity, was approximately 12 -fold greater in NB2a compared with PC12 cells (Table 2). Stable transfection and histochemical staining indicated that $\alpha$-CaMKII promoter activity was qualitatively lower in PC12 (approximately 45-fold) compared with NB2a cells (Fig. 1A). These results are consistent with previous findings using RNase protection assays that showed that the amount of endogenous $\alpha$-CaMKII mRNA is approximately 200-1000-fold lower in PC12 cells than in hippocampus (Massé et al., 1993). Together, these results indicate that the $\alpha$-CaMKII promoter activity is very low in PC12 cells compared with NB2a cells or forebrain pyramidal neurons (Kelly and Cotman, 1981; Fukunaga et al., 1988; Scholz et al., 1988; Walaas et al., 1988; Burgin et al., 1990).

One possible explanation for the low expression of $\alpha$-CaMKII in PC12 cells is that under standard growth conditions PC12 cells are not induced to express high levels of this putative "neuronspecific" protein kinase isoform. Various agents like NGF (Hatanaka, 1981, 1983; Teng et al., 1995), cAMP (Michel et al., 1995), K-252a (Wu and Howard, 1995), and RA (Norikazu and Kenjo, 1989; Scheibe and Wagner, 1992) are known to stimulate expression of neuron-like phenotypes in PC12 cells. We examined PC12 cells under various growth conditions (e.g., cyclic AMP analogs, NGF, and RA) to examine the relationship between neuron-like differentiation and the expression of exogenous or endogenous $\alpha$-CaMKII genes. The promoter activity of exogenous $\mathrm{p} \alpha$ $\mathrm{CaMKII} / \beta$-gal gene in PC12 cells was not affected by NGF, even though NGF induced neurite outgrowth (data not shown). This is consistent with previous studies that showed that PC12 cells respond to NGF by extending neurites and increasing the activity of the catecholamine-synthesizing enzyme tyrosine hydroxylase (Hatanaka, 1981, 1983; Rydel and Greene, 1987), whereas the $\mathrm{Ca}^{2+} / \mathrm{CaM}$-dependent or -independent activities of CaMKII were not affected by NGF or epidermal growth factor (Heasley and Johnson, 1989).

RA stimulated expression of the exogenous $\alpha$-CaMKII gene ( $\mathrm{p} \alpha$-CaMKII $/ \beta$-gal); stimulation was apparent at protein (Fig. 1, $B 5$ vs $B 2$ ) and mRNA levels (Fig. $4 A$ ), whereas NGF and other morphogens did not affect their levels. Stimulation of $\alpha$-CaMKII expression by RA in PC12 cells is probably via an indirect pathway, because it required 12-24 hr of RA treatment (Fig. 3). RA also increased the levels of endogenous $\alpha$-CaMKII mRNA in normal PC12 cells and stimulated neurite outgrowth (Fig. 5).

Is there a physiological role for the stimulation of $\alpha$-CaMKII gene transcription by RAs? RA stimulates neuron-like differen- 

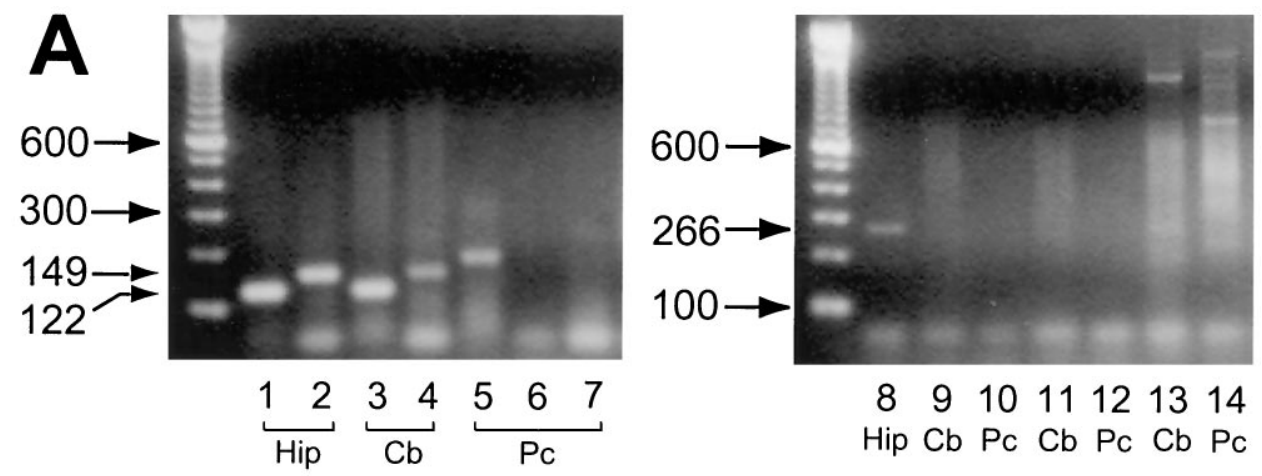

Figure 8. RT-PCR analysis of the $5^{\prime}$ region of $\alpha$-CaMKII mRNAs from rat brain and PC12 cells. $A$, RT-PCR was performed with total RNA from hippocampus (250 ng; lanes $1,2$, and 8$)$ or cerebellum (1 $\mu \mathrm{g}$; lanes 3,4 , $9,11$, and 13$)$, or poly $\left(\mathrm{A}^{+}\right)$RNA from PC12 cells (100 ng; lanes 5-7, 10, 12, and 14). All RT-PCRs used the same 3' RT-primer specific for $\alpha$-CaMKII mRNA ( $\alpha s p)$ and different 5' PCR primers: $\mathrm{p} 1$ (lanes 1, 3, and 5), p2 (lanes 2, 4, 6, and 7), and p5 (lanes 8-14). Note that $\mathrm{p} 1$ and $\mathrm{p} 2$ are separated by $9 \mathrm{nt}$ and flank the ATG translation start codon. $\mathrm{MgSO}_{4}$ concentrations were $0.5 \mathrm{~mm}$ (lanes $1-5,7,8,11$, and 12), $0.05 \mathrm{~mm}$ (lanes 6, 9 , and 10), and $1.0 \mathrm{~mm}$ (lanes 13 and 14). B, Partial map of the $\alpha$-CaMKII gene and the different primers.

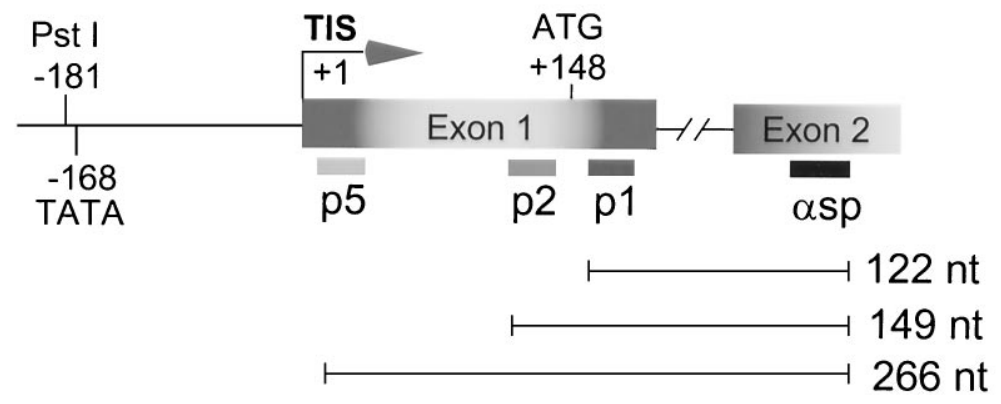

tiation of PC12 cells (Norikazu and Kenjo, 1989; Scheibe and Wagner, 1992) and is essential for nervous system development (Awgulewitsch et al., 1986; Simeone et al., 1986; Durston et al., 1989). In the developing chick limb bud, a functional gradient of RA is distributed spatially with the zone of polarizing activity (Thaller and Eichele, 1987). RA exerts its effects by binding to nuclear RA receptors (RARs) and retinoid X receptors (RXRs) that form heterodimers and modulate transcription of specific genes (Giguere et al., 1987; Leid et al., 1992). RA also binds to cellular RA binding proteins (CRABPs), whose expressions are modulated positively by RA (Smith et al., 1991; Durand et al., 1992; Husmann et al., 1992). CRABP-I binds RA in the cytoplasm (Boylan and Gudas, 1991) and facilitates its catabolism (Napoli et al., 1991; Mangelsdorf et al., 1994). Therefore, in cells expressing high levels of CRABP-I, the amount of RA available to bind to nuclear RARs or RXRs should be less. The function of CRABP-II is less understood (Ruberte et al., 1993), although it is 73\% homologous to CRABP-I (Giguere et al., 1990).

Little is known about the distribution of RA in the developing nervous system, and almost all of the developmental studies on RARs, RXRs, CRABPs, and CRBPs have been carried out in fetal or newborn brain. In contrast, studies on $\alpha$-CaMKII have been conducted on postnatal brain tissues, because its expression is extremely low at birth and major increases occur between postnatal days 7 and 25 (Kelly et al., 1987; Scholz et al., 1988; Weinberger and Rostas, 1988; Burgin et al., 1990). Considering the incomplete knowledge regarding pre- versus postnatal changes in RA-regulated processes, we do not see a unifying relationship between brain regions that express high levels of $\alpha$-CaMKII (i.e., cerebral cortex, hippocampus, and olfactory bulb) and those that express high levels of RARs and/or RXRs or low levels of CRABPs/CRBPs. The expression of RAR $\alpha$ in newborn brain is ubiquitous; $\operatorname{RAR} \beta$ expression is restricted to the caudate/ putamen, nucleus accumbens, and olfactory tubercle, and RAR $\gamma$ is virtually absent (Ruberte et al., 1993). $\operatorname{RXR} \alpha$ and $\operatorname{RXR} \beta$ are expressed ubiquitously in the developing nervous system, whereas $\mathrm{RXR} \gamma$ displays preferential expression in forebrain (Dolle et al., 1994). On the other hand, the expression of CRABP-I in newborn brain is highest in cerebellum, hippocampus, caudate/putamen, and amygdala (Maden et al., 1990; Ruberte et al., 1993), and CRBP-I is high in cerebellum (Maden et al., 1990). Additional studies on RA-regulated mechanisms in the developing postnatal brain are necessary to better understand their relationship to the $\alpha$-CaMKII expression.

Do RARs or RXRs interact directly with the $\alpha$-CaMKII gene? We have examined the $5^{\prime}$ region of the $\alpha$-CaMKII gene for RARand RXR-like response elements (RAREs and RXREs) (Mangelsdorf et al., 1994). We found a direct repeat AGTCCTAGTCC spaced by one nucleotide (i.e., similar to the DR-1 motif AGGTCANAGGTCA) located $47 \mathrm{nt} 5^{\prime}$ of the ATG translation start codon and $100 \mathrm{nt} 3^{\prime}$ of TIS ${ }_{+1}$. RAREs or RXREs can be located in the $3^{\prime}$ flanking region of a gene, like the homeobox gene Hoxb-1 (Marshall et al., 1994). Moreover, many transcriptional regulatory sequences are located $3^{\prime}$ to the TIS (Wondisford et al., 1989; Ayer and Dynan, 1990; Nikovits et al., 1990). The putative DR-1-like RXRE in the $\alpha$-CaMKII gene displays a strong resemblance to the RXRE consensus sequence (Mangelsdorf et al., 1994). We have not examined the involvement of this putative RXR-like DR-1 sequence in the stimulation by RA of $\alpha$-CaMKII gene expression in PC12 cells. Nevertheless, this DR-1 suggests that RA may stimulate the transcription of the $\alpha$-CaMKII gene through the action of RARs and/or RXRs. On the other hand, our observation that the stimulatory effect of RA requires considerable time $(\sim 12 \mathrm{hr})$ suggests that levels of RAR or RXR in our PC12 cells may be low. This prediction is consistent with results showing that the levels of $\operatorname{RAR} \alpha, \beta$, and $\gamma$ expression are low in PC12 cells (Scheibe et al., 1991).

Our identification of TIS T148 $_{+1}$ for the endogenous $\alpha$-CaMKII mRNA in PC12 cells was unexpected, because it places the $5^{\prime}$ end of the $\alpha$-CaMKII mRNA very near the ATG translation start 
codon. This result was verified by both RPA (Fig. 6) and RT-PCR (Fig. 8). TIS ${ }_{+148}$ is virtually absent from rat hippocampus and forebrain where the prominent TIS is at position +1 (TIS $_{+1}$ ). TIS $_{+148}$ is prominent in cerebellum, where TIS $_{+1}$ is minor (Fig. $6)$. TIS $_{+148}$ does not seem to result from the $5^{\prime}$ flanking and the first exon of the $\alpha$-CaMKII gene being altered or missing in PC12 cells, because PCR verified that the $5^{\prime}$ region of PC12 cells and brain were indistinguishable (Fig. 7). These results suggest that cerebellum and PC12 cells contain a specific mechanism(s) that inhibits transcription at $\mathrm{TIS}_{+1}$. Alternatively, PC12 cells and cerebellar neurons may have much lower levels of a specific transcriptional activator(s) that acts at TIS $_{+1}$ and is abundant in forebrain. It is also possible that an editing mechanism, analogous to the RNA editing of the GluR2 glutamate receptor (Sommer et al., 1991), may modify bases near the ATG start codon of the $\alpha$-CaMKII mRNA and make this region hypersensitive to hydrolysis and/or turnover. The existence of such a mechanism in PC12 cells and cerebellum could result in the observed TIS $_{+148}$, even though TIS $_{+1}$ may be the only site of transcription initiation.

In contrast to the endogenous $\alpha$-CaMKII gene, PC12 cells transfected with the $\alpha$-CaMKII $/ \beta$-gal reporter plasmid initiated transcription at a site analogous to TIS $_{+1}$ in hippocampus (Fig. 4). This indicates that the regulation of transcription is different between the exogenous and endogenous $\alpha$-CaMKII promoter. This difference may be attributable to the fact that the exogenous $\alpha$-CaMKII reporter gene contains only $290 \mathrm{nt}$ of $5^{\prime}$ sequence and lacks a $38 \mathrm{nt}$ region between the endogenous TIS and the ATG translation start codon. Recent results from transgenic experiments (Mayford et al., 1995) suggest that up to $8.5 \mathrm{~kb}$ of contiguous $5^{\prime}$ flanking sequence may be required to produce the appropriate developmental and neuron-type specific expression of $\alpha$-CaMKII.

Is there a physiological basis for the different TISs for $\alpha$-CaMKII in hippocampus, cerebellum, or PC12 cells? We speculate that there are functions in $\mathrm{PC} 12$ cells and cerebellar neurons that require very low levels of $\alpha$-CaMKII expression and that this results from transcription at TIS $_{+148}$. Although little is known about the mechanisms regulating transcription in brain and PC12 cells, transcriptional suppressors acting at TIS $_{+1}$ could be present in cerebellum and PC12 cells, and transcription at TIS ${ }_{+148}$ may simply be the default site. It is possible that sequences $5^{\prime}$ to the TATA element of the $\alpha$-CaMKII gene (Olson et al., 1995), and/or sequences between TIS $_{+1}$ and the ATG translation start codon, may inhibit transcription at TIS $_{+1}$ in cerebellum and PC12 cells. Inhibition could involve the action of specific transcriptional repressors or genomic superhelix structures (Liu and Wang, 1987; Chen et al., 1993) near the TIS $_{+1}$ in cerebellum and PC12 cells, which would divert transcription to TIS ${ }_{+148}$. Because the stimulatory effect of RA on $\alpha$-CaMKII gene expression is modest, we believe a better understanding of factors that regulate its transcription at TIS $_{+1}$ versus TIS $_{+148}$ will be critical in describing the developmental and neuron-type specific expression of this major protein kinase in brain.

\section{REFERENCES}

Arts J, Lansink M, Grimbergen J, Toet K, Kooistra T (1995) Stimulation of tissue-type plasminogen activator gene expression by sodium butyrate trichostatin A in human endothelial cells involves histone acetylation. Biochem J 310:171-176.

Ausubel FM, Brent R, Kingston RE, Moore DD, Seidman JG, Smith JA, Struhl K (1987) Current protocols in molecular biology. In: Protein expression (16.20) (Janssen K, ed), pp 4.7.1-6 and 16.20.7-16. New York: Wiley.
Awgulewitsch A, Utset MF, Hart CP, McGinnis W, Ruddle FH (1986) Spatial restriction in expression of a mouse homeobox locus within the central nervous system. Nature 320:328-335.

Ayer DE, Dynan WS (1990) A downstream-element-binding factor facilitates assembly of a functional preinitiation complex at the simian virus 40 major late promoter. Mol Cell Biol 10:3635-3645.

Bach ME, Hawkins RD, Osman M, Kandel ER, Mayford M (1995) Impairment of spatial but not contextual memory of CaMKII mutant mice with a selective loss of hippocampal LTP in the range of the theta frequency. Cell 81:905-915.

Behr J, Demeneix B, Loeffler J, Perez-Mutul J (1989) Efficient gene transfer into mammalian primary endocrine cells with lipopolyaminecoated DNA. Proc Natl Acad Sci USA 86:6982-6986.

Boylan JF, Gudas LJ (1991) Overexpression of the cellular retinoic acid binding protein-I (CRABP I) results in a reduction in differentiationspecific gene expression in F9 teratocarcinoma cells. J Cell Biol 112:965-979.

Burgin KE, Waxham MN, Rickling S, Westgate SA, Mobley WC, Kelly PT (1990) In situ hybridization histochemistry of $\mathrm{Ca}^{2+} /$ calmodulindependent protein kinase in developing rat brain. $\mathrm{J}$ Neurosci 10:1788-1798.

Chen D, Bowater RP, Lilley DM (1993) Activation of the leu-500 promoter: a topological domain generated by divergent transcription in a plasmid. Biochemistry 32:13162-13170.

Chen J, Kelly PT (1994) Functional analysis of cellular and environmental factors regulating transcription of the $\alpha$-subunit of calcium/ calmodulin-dependent protein kinase II ( $\alpha$-CK II). Soc Neurosci Abstr 20:30.6.

Dolle P, Fraulob V, Kastner P, Chambon P (1994) Developmental expression of murine retinoid $\mathrm{X}$ receptor (RXR) genes. Mech Dev 45:91-104.

Donis JA, Montserrat V-M, Neve RL (1993) Comparison of expression of a series of mammalian vector promoter in the neuronal cell lines PC12 and HT4. Biotechniques 15:1-2.

Durand B, Saunders M, Leroy P, Leid M, Chambon P (1992) All-transand 9-cis-retinoic acid induction of CRABP II transcription is mediated by RAR-RXR heterodimers bound to DR-1 and DR-2 repeated motifs. Cell 71:73-85.

Durston AJ, Timmermans J, Hage W, Hendriks H, de Vries N, Heideveld M, Nieuwkoop P (1989) Retinoic acid causes an anteroposterior transformation in the developing central nervous system. Nature 340:140-144.

Erondu NE, Kennedy MB (1985) Regional distribution of type II $\mathrm{Ca}^{2+}$ / calmodulin-dependent protein kinase in rat brain. J Neurosci 5:3270-3277.

Fukunaga K, Goto S, Miyamoto E (1988) Immunohistochemical localization of $\mathrm{Ca}^{2+} /$ calmodulin-dependent protein kinase II in rat brain and various tissues. J Neurochem 51:1070-1078.

Giguere V, Ong ES, Segui P, Evans RM (1987) Identification of receptor for the morphogen retinoic acid. Nature 330:624-629.

Giguere V, Lyn S, Yip P, Siu CH, Evans RM (1990) Molecular cloning of cDNA encoding a second cellular retinoic acid-binding protein. Proc Natl Acad Sci USA 87:6233-6237.

Graham FL, van der Eb AJ (1973) A new technique for the assay of infectivity of human adenovirus 5 DNA. Virology 52:456-459.

Greene LA, Tischler AS (1983) PC12 pheochromocytoma cultures in neurobiological research. Adv Cell Neurobiol 3:373-414.

Hanson PI, Schulman H (1992) Neuronal $\mathrm{Ca}^{2+} /$ calmodulin-dependent protein kinases (review). Annu Rev Biochem 61:559-601.

Hatanaka H (1981) Nerve growth factor-mediated stimulation of tyrosine hydroxylase activity in a clonal rat pheochromocytoma cell line. Brain Res 222:225-233.

Hatanaka H (1983) Nerve growth factor-mediated differentiation of a nerve cell line cultured in a hormone-supplemented serum-free medium. Brain Res 282:243-250.

Haycock JW, Meligeni J, Bennett W, Waymire J (1982) Phosphorylation and activation of tyrosine hydroxylase mediate the acetylcholineinduced increase in catecholamine biosynthesis in adrenal chromaffin cells. J Biol Chem 257:12641-12648.

Heasley L, Johnson G (1989) Detection of nerve growth factor and epidermal growth factor-regulated protein kinase in $\mathrm{PC} 12$ cells with synthetic peptide substrates. Mol Pharmacol 35:331-338.

Husmann M, Hoffmann B, Stump DG, Chytil F, Pfahl M (1992) A retinoic acid response element from the rat CRBP I promoter is 
activated by an RAR/RXR heterodimer. Biochem Biophys Res Commun 187:1558-1564.

Kelly PT, Cotman CW (1981) Developmental changes in morphology and molecular composition of isolated synaptic junctional structures. Brain Res 206:251-271.

Kelly PT, Vernon P (1985) Changes in the subcellular distribution of calmodulin-kinase II during brain development. Brain Res 350:211-224.

Kelly PT, Shields S, Conway K, Yip R, Burgin K (1987) Developmental changes in calmodulin-kinase II activity at brain synaptic junctions: alterations in holoenzyme composition. J Neurochem 49:1927-1940.

Laird PW, Zijderveld A, Linders K, Rudnicki MA, Jaenisch R, Berns A (1991) Simplified mammalian DNA isolation procedure. Nucleic Acids Res 19:4293.

Leid M, Kastner P, Lyons R, Nakshatri N, Saunders M, Zacharewski T, Chen J-W, Staub A, Garnier J-M, Mader S, Chambon P (1992) Purification, cloning of and RXR identification of the HeLa cell factor with which RAR or TR heterodimerizes to bind target sequences efficiently. Cell 68:377-395.

Liu LF, Wang JC (1987) Supercoiling of the DNA template during transcription. Proc Natl Acad Sci USA 84:7024-7027.

Loeffler JP, Barthel F, Feltz P, Behr J, Sassone-Corsi P, Feltz A (1990) Lipopolyamine-mediated transfection allows gene expression studies in primary neuronal cells. J Neurochem 54:1812-1815.

Mackler SA, Brooks BP, Eberwine JH (1992) Stimulus-induced coordinate changes in mRNA abundance in single postsynaptic hippocampal CA1 neurons. Neuron 9:539-548.

Maden M, Ong DE, Chetil F (1990) Retinoid-binding protein distribution in the developing mammalian nerve system. Development 109:75-80.

Malenka RC, Kauer JA, Perkel DJ, Mauk MD, Kelly PT, Nicoll RA, Waxham MN (1989) An essential role for postsynaptic calmodulin and protein kinase activity in long-term potentiation. Nature 340:554-557.

Malinow R, Schulman H, Tsien RW (1989) Inhibition of postsynaptic PKC or CaMKII blocks induction but not expression of LTP. Science 245:862-866.

Mangelsdorf DJ, Umesono K, Evans RM (1994) The retinoids: biology, chemistry, and medicine, 2nd Ed (Sporn MB, Robert AB, Goodman DS, eds). New York: Raven.

Marshall H, Studer M, Popperl H, Aparicio S, Kuroiwa A, Brenner S, Krumlauf R (1994) A conserved retinoic acid response element required for early expression of the homeobox gene Hoxb-1. Nature 370:567-571

Massé T, Dafny N, Kelly PT (1993) Subcellular localization of calcium/ calmodulin-dependent protein kinase II (CK-II) in PC12 cells. Soc Neurosci Abstr 19:107.10.

Matthies H, Palfrey H, Hirning L, Miller R (1987) Down regulation of protein kinase $\mathrm{C}$ in neuronal cells: effects on neurotransmitter release. J Neurosci 7:1198-1206.

Mayford M, Wang J, Kandel ER (1995) CaMKII regulates the frequency-response function of hippocampal synapses for the production of both LTD and LTP. Cell 81:891-904.

Michel P, Vyas S, Agid Y (1995) Synergistic differentiation by chronic exposure to cyclic AMP and nerve growth factor renders rat PC12 cells totally dependent upon tropic support for survival. Eur J Neurosci 7:251-260.

Napoli JL, Posch KP, Fiorella PD, Boerman MHEM (1991) Physiological occurrence, biosynthesis and metabolism of retinoic acid: evidence of cellular retinoid-binding protein (CRBP) and cellular retinoic acidbinding protein (CRABP) in the pathway of retinoic acid homeostasis. Biomed Pharmacother 45:131-143.

Nikovits W, Mar JH, Ordahl CP (1990) Muscle-specific activity of the skeletal troponin I promoter requires interaction between upstream regulatory sequences and elements contained within the first transcribed exon. Mol Cell Biol 10:3468-3482.

Norikazu M, Kenjo K (1989) Possible involvements of intracellular $\mathrm{Ca}^{2+}$ and $\mathrm{Ca}^{2+}$-dependent protein phosphorylation in cholinergic differentiation of clonal rat pheochromocytoma cells (PC12) induced by gliomaconditioned medium and retinoic acid. Dev Brain Res 50:1-10.

Nose P, Griffith LC, Schulman H (1985) $\mathrm{Ca}^{2+}$-dependent phosphorylation of tyrosine hydroxylase in PC12 cells. J Cell Biol 101:1182-1190.

Olson NJ, Masse T, Suzuki T, Chen J, Alam D, Kelly PT (1995) Functional characterization of the promoter for the $\alpha$-subunit of $\mathrm{Ca}^{2+}$ calmodulin-dependent protein kinase II. Proc Natl Acad Sci USA 92:1659-1663.

Ruberte E, Friederich V, Chambon P, Morriss-Kay G (1993) Retinoic acid receptors and cellular retinoid binding proteins. III. Their differ- ential transcript distribution during mouse nervous system development. Development 118:267-282.

Rydel RE, Greene L (1987) Acidic and basic fibroblast growth factors promote stable neurite outgrowth and neuronal differentiation in cultures of PC12 cells. J Neurosci 7:3639-3652.

Sanes JR (1986) Use of recombinant retrovirus to study postimplantation cell lineage in mouse embryos. EMBO J 5:3133-3142.

Scheibe RJ, Wagner JA (1992) Retinoic acid regulates both expression of the nerve growth factor receptor and sensitivity to nerve growth factor. J Biol Chem 267:17611-17616.

Scheibe RJ, Ginty DD, Wagner JA (1991) Retinoic acid stimulates the differentiation of PC12 cells that are deficient in cAMP-dependent protein kinase. J Cell Biol 113:1173-1182.

Scholz WK, Baitinger C, Schulman H, Kelly PT (1988) Developmental changes in $\mathrm{Ca}^{2+}$ /calmodulin-dependent protein kinase II in cultures of hippocampal pyramidal neurons and astrocytes. $\mathrm{J}$ Neurosci 8:1039-1051.

Silva A, Paylor R, Wehner J, Tonegowa S (1992) Impaired spatial learning in alpha-calcium-calmodulin kinase II mutant mice. Science 257:206-211.

Simeone A, Mavilio F, Bottero L, Giampaolo A, Russo G, Faiella A, Boncinelli E, Peschle C (1986) A human homoeo box gene specifically expressed in spinal cord during embryonic development. Nature 320:763-765.

Smith WC, Nakshatri H, Leroy P, Rees J, Chambon P (1991) A retinoic acid response element ia present in the mouse cellular retinol binding protein I (mCRBPI) promoter. EMBO J 10:2223-2230.

Sommer B, Kohler M, Sprengel R, Seeburg PH (1991) RNA editing in brain controls a determinant of ion flow in glutamate-gated channels. Cell 67:11-19.

Sunyer T, Sahyoun N (1990) Sequence analysis and DNA-protein interactions within the $5^{\prime}$ flanking region of the $\mathrm{Ca}^{2+} /$ calmodulin-dependent protein kinase II alpha-subunit gene. Proc Natl Acad Sci USA 87:278-282.

Teng K, Lander H, Fajardo J, Hanafusa H, Hempstead B, Birge R (1995) $\mathrm{v}$-Crk modulation of growth factor-induced PC12 cell differentiation involves the Src homology 2 domain of v-Crk and sustained activation of the Ras/mitogen-activated protein kinase pathway. J Biol Chem 270:20677-20685.

Thaller C, Eichele G (1987) Identification and spatial distribution of retinoids in the developing chick limb bud. Nature 327:625-628.

Thomas KL, Laroche S, Errington ML, Bliss TVP, Hunt SP (1994) Spatial and temporal changes in signal transduction pathways during LTP. Neuron 13:737-745.

Tischler AS, Greene LA (1975) Nerve growth factor-induced process formation by cultured rat pheochromocytoma cells. Nature 258:341-342.

Tischler AS, Dichter MA, Biales B, Greene LA (1977) Neuroendocrine neoplasms and their cells of origin. Semin Med Beth Israel Hosp 296:919-925.

Tobimatsu T, Fujisawa H (1989) Tissue-specific expression of four types of rat calmodulin-dependent protein kinase II m RNAs. J Biol Chem 264:17907-17912.

Tso JY, Sun XH, Kao T, Reece KS, Wu R (1985) Isolation and characterization of rat and human glyceraldehyde-3-phosphate dehydrogenase cDNAs: genomic complexity and molecular evolution of the gene. Nucleic Acids Res 13:2485-2502.

Walaas SI, Lai Y, Gorelick FS, DeCamilli P, Moretti M, Greengard P (1988) Cell-specific localization of the alpha-subunit of calcium/ calmodulin-dependent protein kinase II in Purkinje cells in rodent cerebellum. Brain Res 464:233-242.

Wang J, Kelly PT (1995) Postsynaptic injection of $\mathrm{Ca}^{2+} / \mathrm{CaM}$ induces synaptic potentiation requiring CaMKII and PKC Activity. Neuron 15:443-452.

Weinberger RP, Rostas JAP (1988) Developmental changes in protein phosphorylation in chicken forebrain II: calmodulin stimulated phosphorylation. Dev Brain Res 43:259-272.

Wondisford FE, Farr EA, Radovick S, Steinfelder HJ, Moates JM, McClaskey JH, Weintraub BD (1989) Thyroid hormone inhibition of human thyrotropin beta-subunit gene expression is mediated by a cis-acting element located in the first exon. J Biol Chem 264: 14601-14604.

Wu C, Howard B (1995) K252a-potentiation of EGF-induced neurite outgrowth from PC12 cells is not mimicked or blocked by other protein kinase activators or inhibitors. Brain Res Dev Brain Res 86:217-226. 